\title{
GLYPHOSATE SORPTION AND DESORPTION IN SOILS WITH DISTINCT PHOSPHORUS LEVELS
}

\author{
Fábio Prata1*; Vanessa Camponez do Brasil Cardinali3,4; Arquimedes Lavorenti2; Valdemar \\ Luiz Tornisielo ${ }^{3}$ J Jussara Borges Regitano ${ }^{3}$ \\ 'BIOAGRI Laboratórios - Divisão de Química - Lab. de Radioquímica, C.P. 573 - Rod. Rio Claro/Piracicaba SP 127, \\ Km 24 - CEP: 13412-000 - Piracicaba, SP \\ ${ }^{2}$ Depto. de Ciências Exatas - USP/ESALQ, C.P. 9 - CEP: 13418-900 - Piracicaba, SP. \\ ${ }^{3}$ Seção de Ecotoxicologia - USP/CENA, C.P. 96 - CEP: 13400-970 - Piracicaba, SP. \\ ${ }^{4}$ FAPESP Fellow. \\ ${ }^{*}$ Corresponding author <fabioprata@bioagri.com.br>
}

\begin{abstract}
The sorption of glyphosate by soils occurs due to the inner sphere complex formation with metals of soil oxides, which are related to the soil phosphate adsorption capacity. The aim of this study was to evaluate the effects of increasing rates of phosphorus on sorption and desorption of glyphosate in three soils with different mineralogical attributes. Soils were a Rhodic Kandiudalf, an Anionic Acrudox and a Typic Humaquept. Soil samples were amended with $\mathrm{KH}_{2} \mathrm{PO}_{4}$ at equivalent rates of $0 ; 1,000 ; 5,000 ; 20,000$ and $50,000 \mathrm{~kg} \mathrm{ha}^{-1}$ of $\mathrm{P}_{2} \mathrm{O}_{5}$, which are high from the agricultural point of view, but necessary in order to perform sorption and desorption studies. The experimental design consisted of a completely randomized factorial: 2 soils $x 5$ phosphorus rates and 3 replicates. For the sorption experiments, five glyphosate solutions were

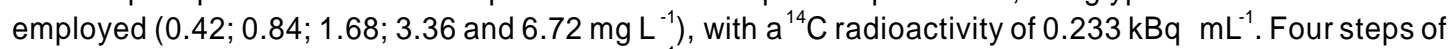
the desorption procedure with $\mathrm{CaCl}_{2} 0.01 \mathrm{~mol} \mathrm{~L}^{-1}$ and one extraction with Mehlich 3 were performed only at one concentration $\left(0.84 \mathrm{~mol} \mathrm{~L}^{-1}\right)$. Soil samples were afterwards biologically oxidized to establish the radioactive balance. Glyphosate competes with phosphorus for specific sorption sites, but this competition becomes important when phosphorus is present at rates higher than $1,000 \mathrm{mg} \mathrm{dm}^{-3}$. Moreover, a small amount of applied glyphosate was extracted $(<10 \%)$, and the extraction increased with increasing soil phosphorus content.
\end{abstract}

Key words: herbicide, retention, bound residue, phosphate, oxides

\section{SORÇÃO E DESSORÇÃO DE GLIFOSATO EM SOLOS COM DISTINTOS NÍVEIS DE FÓSFORO}

\begin{abstract}
RESUMO: A sorção do glifosato no solo ocorre devido a formação de complexos de esfera interna com os metais dos óxidos, o que está relacionado à capacidade dos solos em adsorver fosfatos. Isto sugere que haja competição entre o herbicida e os íons fosfato pelos sítios de adsorção específica do solo. Com isso, o presente trabalho teve o objetivo de verificar a extensão do efeito de níveis crescentes de fósforo no solo na sorção e dessorção do glifosato em solos com diferentes atributos mineralógicos. Os solos foram Nitossolo Vermelho eutroférrico, Latossolo Amarelo ácrico e Gleissolo. Amostras dos solos foram incubadas com $\mathrm{KH}_{2} \mathrm{PO}_{4}$, por 30 dias, nas doses equivalentes a 0;1000; $5000 ; 20000$ e $50000 \mathrm{~kg} \mathrm{ha}^{-1} \mathrm{deP}_{2} \mathrm{O}_{5}$, que são muito altos do ponto de vista agronômico, mas necessário para estudos de sorção e dessorção. O delineamento experimental foi do tipo inteiramente casualizado, em arranjo fatorial 3 (solos) X 5 (níveis de fósforo no solo), com três repetições. No estudo da sorção foram utilizadas cinco concentrações do herbicida: 0,42; 0,84; 1,68; 3,36 e 6,72 $\mathrm{mg} \mathrm{L}^{-1}$, com radioatividade $\left({ }^{14} \mathrm{C}\right)$ de $0,233 \mathrm{kBq} \mathrm{mL} \mathrm{L}^{-1}$. Apenas para a concentração $0,84 \mathrm{mg} \mathrm{L}^{-1}$ foram feitas quatro dessorções com CaCl $20,01 \mathrm{~mol} \mathrm{~L}^{-1}$ e uma extração com extrator Mehlich 3. Posteriormente, alíquotas do solo foram oxidadas em oxidador biológico para o fechamento do balanço de radioatividade. O glifosato compete com o fósforo pelos sítios de sorção específica no solo, mas essa competição somente é importante quando os níveis de $\mathrm{P}$ atingem valores superiores a $1000 \mathrm{mg} \mathrm{dm}^{-3}$. A extração do glifosato foi muito baixa e foi acrescida com aumento dos níveis de $\mathrm{P}$ no solo.

Palavras-chave: herbicida, retenção, resíduo ligado, fosfato, óxidos
\end{abstract}

\section{INTRODUCTION}

Glyphosate [n(phosphonomethyl)glycine], the active ingredient of the world wide best-selling herbicide (Mendelson, 1998), is a non-selective molecule widely utilized in Brazil as a desiccant in no-till crops, between rows of perennial crops and for the elimination of weeds in aquatic environments (Rodrigues \& Almeida, 1995). This herbicide is applied after emergence and presents aposymplastic translocation. It acts by inhibiting the enzyme 6-enolpyruvylshikimate-3-phosphate synthase (EPSPS), interfering with the amino acid biosynthesis (Roberts et al., 1998). In most cases the glyphosate is not metabolized by plants and this is why it is not 
selective. Only varieties genetically altered for this are resistant to this herbicide. Thus, practically all of the active ingredient concentration that is applied reaches the soil in its original form.

In the soil, the glyphosate is characterized by its high sorption capacity, as it can show partition coefficient values of the order of $1,188 \mathrm{~mL} \mathrm{~g}^{-1}$ (Cheah et al., 1997). Several binding mechanisms have been suggested for the sorption of this herbicide, such as: electrostatic bonds in extremely acid media (Miles \& Moye, 1988), hydrogen bonds with humic substances (Piccolo et al., 1996) and, especially, covalent bonds with $\mathrm{Fe}$ and Al oxides (Piccolo et al., 1994; Cheah et al., 1997; Prata et al., 2000). However, the presence of these mechanisms is only suggested by the authors and, except for the report of Piccolo et al. (1996), who presented more detailed results on the binding mechanism itself, these suggestions are based on sorption and desorption studies with different treatments.

Prata et al. (2000) studied the influence of organic matter on glyphosate sorption and desorption in three soils with different mineralogical attributes and verified that the sorption of this herbicide was not related to the organic, but to the mineral fraction of these soils, more specifically to $\mathrm{Fe}$ and Al oxides. In this work they also verified that the molecule could not be extracted by a saline aqueous extractor, remaining in the soil as a bound residue.

The dissipation of glyphosate, expressed by means of its half-life $\left(t_{1 / 2}\right)$, varies considerably with soil type and is largely due to the formation of bound residues. The half-life for glyphosate dissipation has mean values of 38 days (Rueppel et al., 1977). On the other hand, its half-life for mineralization can reach values as high as 22.7 years (Nomura \& Hilton, 1977) as a reflex of its high sorption rate.

The relationship between glyphosate sorption and the soil capacity to adsorb phosphates is clear in the literature (Hance, 1976; Glass, 1987; Miles \& Moye, 1988; Gerritse et al., 1996) which is probably related to the specific phosphorus adsorption mechanism in the soil, i.e., the formation of sharing covalent bonds between one oxygen from a phosphate and a metal from an oxide. Thus, because of its methylphosphonic group, glyphosate could compete with inorganic phosphates for sorption sites.
Therefore, the objective of this project was to verify the extent of the effect of $P$ levels in the soil on the sorption and desorption of glyphosate.

\section{MATERIAL AND METHODS}

The assays were carried out in Piracicaba-SP, Brazil and the experiments were performed on samples of three soils, classified as Rhodic Kandiudalf (NVef), Anionic Acrudox (LAw), and Typic Humaquept (G). Samples were collected in the $0-20 \mathrm{~cm}$ layer, in the municipal districts of Ribeirão Preto-SP, Guaíra-SP, and Piracicaba-SP, Brazil, respectively. After collection, soil samples were air-dried and passed through a $2 \mathrm{~mm}$ mesh sieve. Results of the chemical, granulometric, and mineralogical analyses are described in Table 1. The chemical analyses were performed according to Raij \& Quaggio (1983), and the organic carbon content was determined by the combustion method (Nelson \& Sommers, 1982). The granulometric analyses were performed according to Camargo et al. (1986). $\mathrm{Fe}\left(\mathrm{Fe}_{2} \mathrm{O}_{3}\right)$ was extracted with a $18 \mathrm{~mol} \mathrm{~L}^{-1} \mathrm{H}_{2} \mathrm{SO}_{4}$ solution (Jackson, 1969). The predominant clay minerals were determined by $\mathrm{X}$-rays diffraction. Subsamples saturated with $\mathrm{K}^{+}$were irradiated at 25; 350 ; and $550^{\circ} \mathrm{C}$. Those saturated with $\mathrm{Mg}^{2+}$ were irradiated at room temperature in two steps, before and after solvation with ethylene glycol, respectively. The kaolinite and gibbsite fractions were quantified by thermo-differential analysis (TDA) (Jackson, 1969).

The experimental design consisted of a completely randomized setup, arranged as a 3 (soils) $\times$ 5 (soil P levels) factorial experiment, with three replicates.

Samples from each soil were incubated with $\mathrm{KH}_{2} \mathrm{PO}_{4}$ in $500 \mathrm{~mL}$ beakers, so that the phosphorus content in the soils would reach the desired levels, with high rates from the agricultural point of view, but required for sorbtion/desorbtion studies and equivalent to 0; 1,000; $5000 ; 20000$ and $50000 \mathrm{~kg} \mathrm{ha}^{-1} \mathrm{P}_{2} \mathrm{O}_{5}$, considering soil bulk density as $1 \mathrm{~g} \mathrm{~cm}^{-3}$ and a soil layer of $0.20 \mathrm{~m}$. The incubation period for $\mathrm{KH}_{2} \mathrm{PO}_{4}$ reaction in the soils was 30 days, and the soil moisture content during this period was kept at $60 \%$ of field capacity.

After the incubation period, samples were airdried, clods broken and passed again through a $2 \mathrm{~mm}$ mesh sieve in order to determine $P$ levels attained,

Table 1 - Chemical characteristics, granulometric and mineralogical attributes of the soils Rhodic Kandiudalf (NVef), Anionic Acrudox (LAw) and Typic Humaquept (G).

\begin{tabular}{|c|c|c|c|c|c|c|c|c|c|c|c|c|c|c|c|c|c|c|}
\hline Soil & $\mathrm{pH}_{\mathrm{H} 2 \mathrm{O}}$ & $\mathrm{C}_{\text {org }}$ & $\mathrm{P}$ & $\mathrm{K}$ & $\mathrm{Ca}$ & $\mathrm{Mg}$ & $\mathrm{H}+\mathrm{Al}$ & $\mathrm{Al}$ & CTC & Sand & Silt & Clay & $\mathrm{Al}^{2} \mathrm{O}^{3}$ & $\mathrm{Fe}^{2} \mathrm{O}^{3}$ & \multicolumn{4}{|c|}{ Clay Mineralogy } \\
\hline & & $\mathrm{g} \mathrm{kg}^{-1}$ & $g \mathrm{dm}$ & 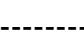 & 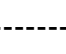 & $\mathrm{mmo}$ & Ic $\mathrm{dm}^{-3}$ & -.-- & 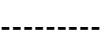 & --.-- & 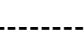 & $\mathrm{g} \mathrm{kg}^{-1}$ & 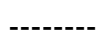 & ------ & $\mathrm{Cau}^{1}$ & $G b^{2}$ & $\mathrm{VH} \mathrm{I}^{3}$ & $\mathrm{~V}^{4}$ \\
\hline NVef & 6.1 & 27.5 & 20 & 3.6 & 74 & 28 & 59 & 2 & 164.6 & 250 & 200 & 550 & 183 & 298 & +++++ & + & - & - \\
\hline Law & 5.5 & 18.9 & 10 & 1.4 & 3 & 3 & 36 & 6 & 43.6 & 590 & 60 & 350 & 113 & 59 & ++++ & ++ & - & - \\
\hline G & 4.2 & 78.5 & 36 & 3.9 & 13 & 8 & 380 & 88 & 404.9 & 200 & 260 & 540 & - & - & ++++ & + & + & ++ \\
\hline
\end{tabular}

${ }^{1}$ Kaolinite, ${ }^{2}$ gibsite, ${ }^{3}$ vermiculite with hydroxyl in the interlayers, ${ }^{4}$ vermiculite,,+++++ Proportion of clay minerals. 
Table 2 - Rates of applied P, soil P levels, electric conductivity (EC) and $\mathrm{pH}$ after 30 days of incubation in the soils Rhodic Kandiudalf (NVef), Anionic Acrudox (LAw) and Typic Humaquept (G).

\begin{tabular}{lrrrr}
\hline Soil & Applied $\mathrm{P}$ & $\mathrm{P}$ Level & $\mathrm{EC}$ & $\mathrm{pH}_{\mathrm{H}_{2} \mathrm{O}}$ \\
\hline \multirow{2}{*}{ NVef } & $\mathrm{kg}_{2} \mathrm{O}_{5} \mathrm{ha}^{-1}$ & $\mathrm{mg} \mathrm{dm}^{-3}$ & $\mathrm{mS} \mathrm{cm}^{-1}$ & \\
& 0 & 20 & 0.532 & 6.1 \\
& 1000 & 208 & 0.605 & 6.2 \\
& 5000 & 1051 & 0.768 & 6.2 \\
& 20000 & 4286 & 2.740 & 6.4 \\
& 50000 & 10799 & 9.890 & 6.4 \\
LAw & 0 & 10 & 0.269 & 5.5 \\
& 1000 & 211 & 0.435 & 5.7 \\
& 5000 & 1009 & 0.784 & 5.9 \\
& 20000 & 4250 & 3.080 & 5.8 \\
& 50000 & 10622 & 8.910 & 5.9 \\
$\mathrm{G}$ & 0 & 36 & 0.262 & 4.2 \\
& 1000 & 223 & 0.372 & 4.5 \\
& 5000 & 1030 & 0.635 & 4.6 \\
& 20000 & 4313 & 2.120 & 4.6 \\
& 50000 & 10819 & 9.770 & 4.8 \\
\hline
\end{tabular}

electric conductivity and $\mathrm{pH}$ (Table 2). The $\mathrm{P}$ and $\mathrm{pH}$ analyses were performed according to Raij \& Quaggio (1983), and the electric conductivity by conductivimetry (cell width $=1 \mathrm{~cm}$ ); the sorption and desorption assays were carried out afterwards.

Five solutions of different glyphosate concentrations were utilized for the sorption tests: 0.42 ; $0.84 ; 1.68 ; 3.36$ and $6.72 \mathrm{mg} \mathrm{L}^{-1}$, in order to carry out the isotherm study. The $0.84 \mathrm{mg} \mathrm{L}^{-1}$ concentration for the soil to solution ratio of 1:5 corresponded to the maximum recommended field rate.

Solutions were prepared in $0.01 \mathrm{~mol} \mathrm{~L}^{-1} \mathrm{CaCl}_{2}$, Two $\mathrm{g}$ soil samples and $10 \mathrm{~mL}$ solution aliquots were placed in $50 \mathrm{~mL}$ centrifuge vials, in three replicates, which were horizontally agitated $(200 \mathrm{~g})$ for 6 hours at $25 \pm 2^{\circ} \mathrm{C}$. Subsequently, the suspended content was centrifuged (3000 g, for $10 \mathrm{~min}$.) and a $1-\mathrm{mL}$ aliquot of the supernatant was removed to determine the radioactivity of the equilibrium solution $\left(C_{e}\right)$ by liquid scintillation spectrometry (LSS). The herbicide concentration could be calculated by using the ${ }^{14} \mathrm{C}$-glyphosate specific activity. In order to do that, we assumed that all radioactivity would be in the glyphosate form. The amount sorbed to the soil was determined by the difference between the initial concentration and the concentration at equilibrium.

For the desorption study, the supernatants from centrifuge vials were discarded and $10 \mathrm{~mL}$ aliquots of the $0.01 \mathrm{~mol} \mathrm{~L}^{-1} \mathrm{CaCl}_{2}$ solution were added only to the 0.84 $\mathrm{mg} \mathrm{L}^{-1}$ concentration sample. Subsequently, the vials were agitated and centrifuged, and the new supernatant was discarded in the same way as for the sorption test. This procedure was repeated other three times.
Sequentially, an attempt was made for extraction by adding $10 \mathrm{~mL}$ of Mehlich 3 solution (Mehlich, 1984). At the end of this step, soil samples were air-dried and homogenized, and subsamples $(0.4 \mathrm{~g})$ were removed and oxidized in a biological oxidizer to determine, by LSS, the radioactivity remaining in the soil. This allowed to establish the radioactive mass balance.

Freundlich's mathematical model was utilized to calculate the sorption and desorption constants: Log $S$ $=\log \mathrm{K}_{\mathrm{f}}+\mathrm{N} \log \mathrm{C}_{\mathrm{e}}$, where $\mathrm{S}$ is the sorbed glyphosate concentration $\left(\mu \mathrm{g} \mathrm{g}^{-1}\right), \mathrm{C}_{\mathrm{e}}$ the glyphosate concentration in the equilibrium solution $\left(\mu \mathrm{g} \mathrm{mL}^{-1}\right), \mathrm{K}_{\mathrm{f}}$ the Freundlich sorption or desorption constant, and $\mathrm{N}$ the linearity degree of the isotherm.

Regression analyses were performed between the increasing levels of $P$ in the treatments and Freundlich constants, as well as for the total sorbed percentage. Analyses of variance and mean comparison tests (Tukey, $P<0.05$ ) were run for the percentages of glyphosate extracted and desorbed.

\section{RESULTS AND DISCUSSION}

Glyphosate sorption in the three studied soils was influenced by the soil P level, and the amount of sorbed glyphosate became substantially reduced at $\mathrm{P}$ levels starting from $1000 \mathrm{mg} \mathrm{dm}^{-3}$ (Figure 1). This visualization of a reduction in glyphosate sorption, however lacks of practical importance, since these phosphorus levels would never be attained under field conditions in agricultural soils, which suggests that under this condition the competition between glyphosate and $\mathrm{P}$ for covalent binding sites in the soil must not occur. Thur, these results confirm that the extent of the binding forces in glyphosate is proportional to the soil capacity of adsorbing inorganic phosphate, as pointed out by other authors (Hance, 1976; Glass, 1987; Miles \& Moye, 1988; Gerritse et al., 1996), suggesting the importance of covalent bonds between the methylphosphonic group of glyphosate and the metals in soil oxides.

The relationship between glyphosate sorption and the levels of $P$ in the soil (Figure 1), indicates that with phosphorus content values in soils of 6871,7031 and $9744 \mathrm{mg} \mathrm{dm}^{-3}$, for NVef, LAw and G soils, respectively, the sorption of the herbicide would be reduced to $50 \%$. This difference, which is observed when the effect of the level of $P$ on herbicide sorption in the NVef and LAw soils is compared to the Inceptisol, can be explained by the content of oxides, especially Fe and Al of the two first soils (Table 1). This again suggests the great importance of covalent bond sites for glyphosate sorption, and also suggests the existence of other binding mechanisms, especially for the Inceptisol.

Prata et al. (2000), studying the effect of organic matter on glyphosate sorption in the same soils, also suggested that the main binding mechanism for glyphosate is the covalent bond between the herbicide and the metals from soil oxides. 
However, even as a secondary role, organic matter plays also a very important role for glyphosate retention, especially in oxide-poor soils such as the Inceptisol (Figures 1 and 2). For this soil, the smaller effect of the $\mathrm{P}$ levels in reducing glyphosate sorption, as compared to the other two soils, is expressive. The initial sorption $(P$ rate $=0)$ is, however, still very high, suggesting that another binding mechanism is also present in this case.
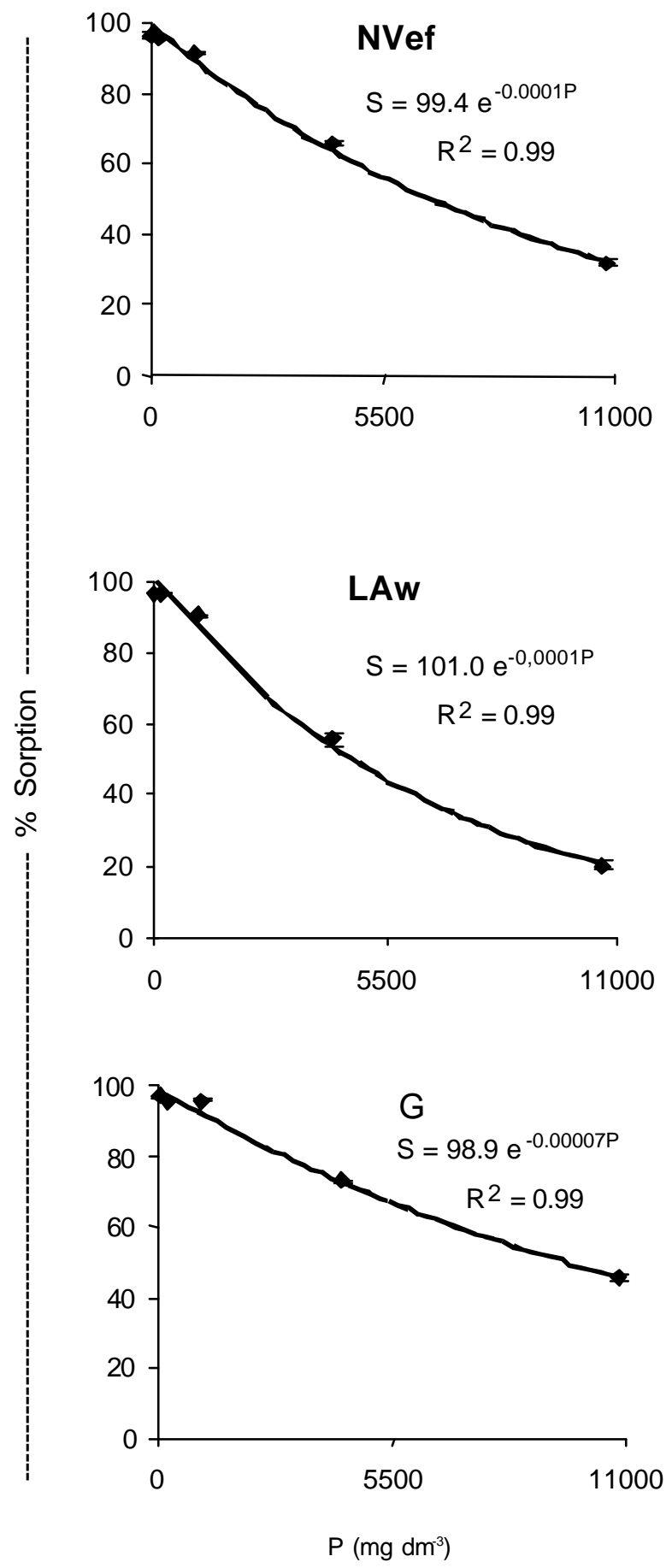

Figure 1 - Glyphosate sorption in the soils Rhodic Kandiudalf (NVef), Anionic Acrudox (LAw) and Typic Humaquept (G), fertilized with increasing rates of $P$. Vertical bars correspond to standard deviations from the mean.
Piccolo et al. (1996) studied glyphosate sorption to humic substances and verified much lower $K_{f}$ values than those obtained in this study for the initial $P$ concentration (Figure 2), although very high, and credited them to the hydrogen bonds between the herbicide molecule and the humic substances. This behavior can be considered glyphosate-specific, since this organic molecule is highly soluble in water $\left(\mathrm{S}_{\mathrm{w}}=11.6 \mathrm{~g} \mathrm{~L}^{-1}\right)$ and is almost insoluble in organic solvents. It is, therefore, a
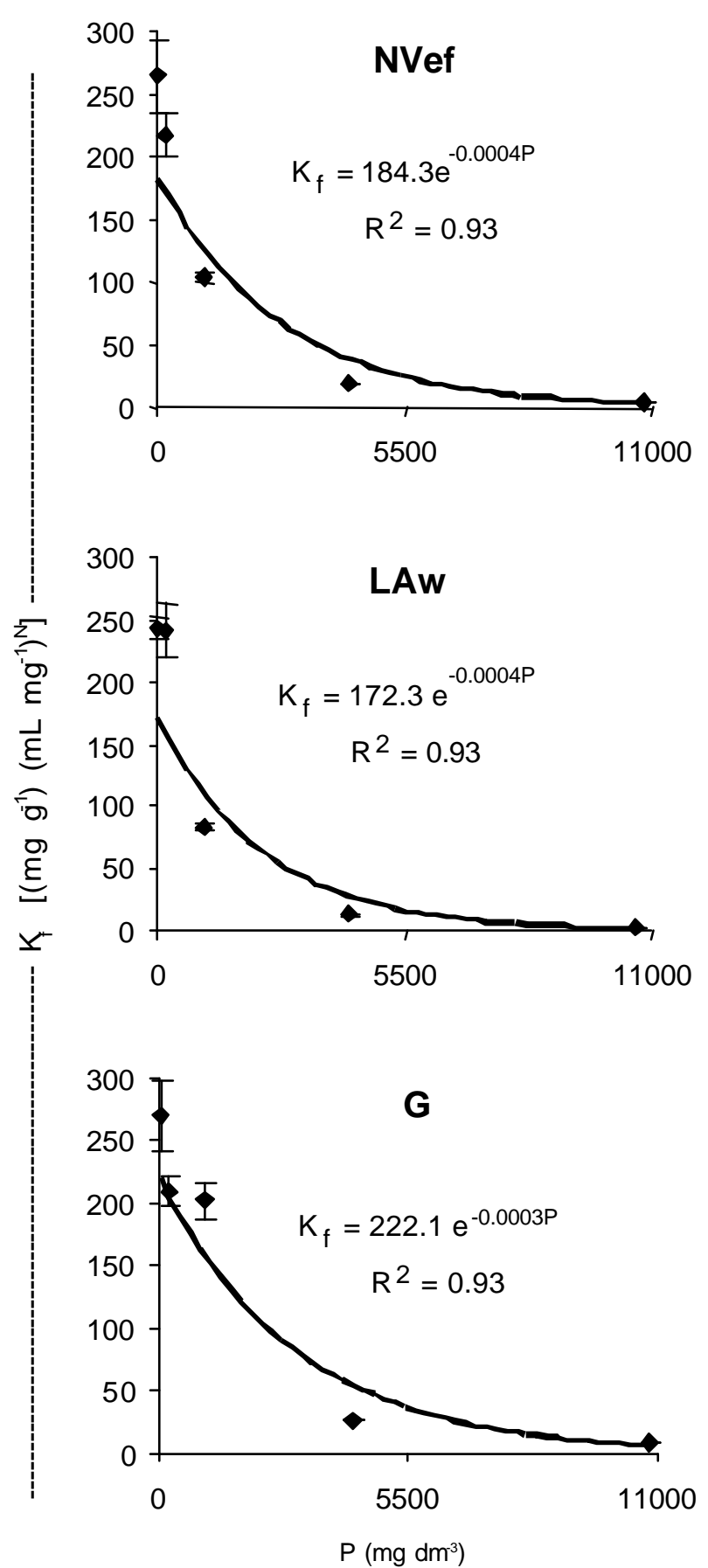

Figure 2 - Freundlich coefficients $(\mathrm{K})$ for glyphosate in the soils Rhodic Kandiudalf (NVef), Anionic Acrudox (LAw) and Typic Humaquept (G), fertilized with increasing rates of $P$. Vertical bars correspond to standard deviations from the mean. 
molecule with low hydrophobicity ( $\log \mathrm{K}_{\mathrm{ow}}=-4.1$ ) which, contrary to what would be expected, presents high sorption.

Like shown for the sorbed percent data, the Freundlich constant values also show, through regression analyses (Figure 2), that significant reductions $\left\{\left(\mathrm{K}_{\mathrm{f}}<50\right.\right.$ $\left.\left[\left(\mathrm{mg} \mathrm{g}^{-1}\right)\left(\mathrm{mL} \mathrm{mg}^{-1}\right)^{\mathrm{N}}\right]\right\}$ occur at levels of $\mathrm{P}$ higher than $1000 \mathrm{mg} \mathrm{dm}^{-3}$.

The fact that the applied rates of $\mathrm{KH}_{2} \mathrm{PO}_{4}$ increased the electric conductivity and $\mathrm{pH}$ of the soils, does not constitute a relevant fact related to changes in sorption for the soils under study. This could occur in the case of incipiently weathered soils, with predominance of 2:1 clay minerals and, especially, in very low $\mathrm{pH}$ medium, in which electrostatic bonds would play an important role in the sorption of this herbicide (McConnell \& Hossner, 1986). Because of its zwitterionic character, at $\mathrm{pH}$ values below 2.23 glyphosate begins to present a positive net charge (Maqueda et al., 1998), and, in these special cases, the importance of electrostatic attractions becomes evident.

The total extraction of glyphosate (desorptions + extraction) intensified due to increasing levels of $P$ in the soil (Figure 3), can be disregarded in relation to the usual low levels of $P$ found in agricultural soils. Even for treatments with the highest $\mathrm{P}$ contents, the total extraction was low, around $10 \%$ of the total sorbed for LAw and NVef (Figure 3). No extraction was observed for the Inceptisol.

Desorptions with $\mathrm{CaCl}_{2}$ and the total extraction increased proportionally with $\mathrm{P}$ levels in the soil (Figure 3 ), and were more important than the extraction with Mehlich 3 for the treatments with highest $P$ contents, which is probably directly related to the increase in ionic strength of the soil solution of these treatments. Miles \& Moye (1988) also observed that glyphosate desorption increased with the increase of ionic strength and $\mathrm{pH}$, in spite of being relatively low, as in this study. However, these results must be analyzed with caution, since the increase in electric conductivity and $\mathrm{pH}$ at the highest rates of $\mathrm{P}$ could have favored clay dispersion in NVef and LAw, which are soils with variable charge. This would imply in measuring sorbed glyphosate on microparticles suspended in the equilibrium solution, which could have been accounted for as desorbed glyphosate. This is a very important aspect, since it is directly related to glyphosate molecule movement in the soil, even in its bound residue form. Glyphosate leaching in a Danish soil was observed by Jonge et al. (2000) in undisturbed columns. In their study, the $\mathrm{K}_{\mathrm{f}}$ value obtained was high $\left\{59\left[\left(\mathrm{mg} \mathrm{g}^{-1}\right)\left(\mathrm{mL} \mathrm{mg}^{-1}\right)^{\mathrm{N}}\right]\right\}$ and the radioactivity in the leachate, transformed into glyphosate concentration, varied proportionally to the turbidity of the solution, indicating that glyphosate was undergoing leached the form of a bound residue. These results of Jonge et al. (2000) also suggest a clay dispersion effect.

Glyphosate extraction has been reported in few studies of the literature (Miles \& Moye, 1988; Prata et

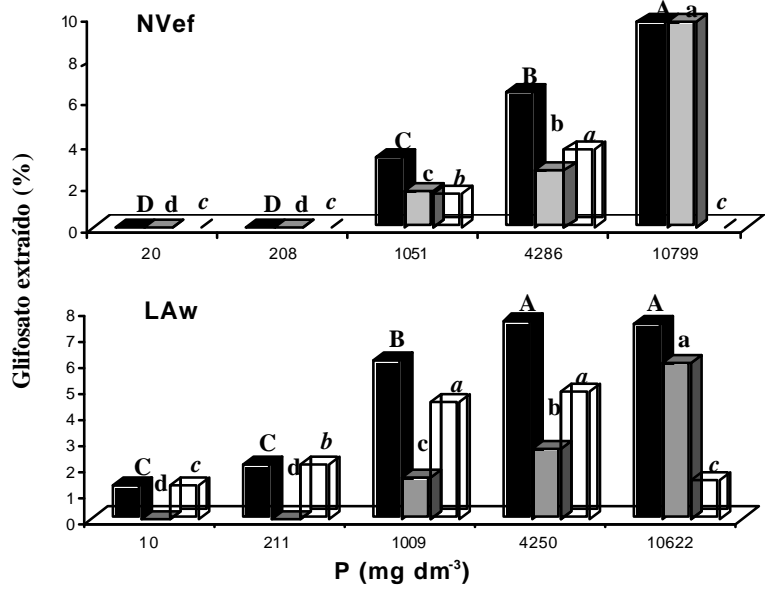

Total extraction (desorption + extraction)

Desorption

Extraction

Figure 3 - Total extraction (4 desorptions + extraction), desorption and extraction of glyphosate in the soil Rhodic Kandiudalf (NVef) and Anionic Acrudox (LAw) with increasing phosphorus levels. Common letters indicate that there is no statistical difference between means by the Tukey test $(P<0.05)$.

al., 2000), which indicates that the main fate of this molecule in soils is the formation of a bound residue, which is one of the main forms of pesticide dissipation in the environment. Nevertheless, the identity and bioavailability of this form of the herbicide is not yet clarified.

\section{CONCLUSIONS}

Glyphosate competes with phosphorus for specific sorption sites of the soil, but this competition becomes only important when the soil $\mathrm{P}$ levels reach very high values, which are not attained under agricultural field conditions. The herbibide extraction is low and increases with $\mathrm{P}$ levels in the soil. Glyphosate remains in the soil as a bound residue.

\section{ACKNOWLEDGEMENT}

\section{To FAPESP for financial support.}

\section{REFERENCES}

CAMARGO, O.A.; MONIZ, A.C.; JORGE, J.A.; VALADARES, J.M. Métodos de análise química, mineralógica e física de solos do Instituto Agronômico de Campinas. Campinas: Instituto Agronômico, 1986. 94p. (Boletim Técnico, 106).

CHEAH, U.B.; KIRKWOOD, R.C.; LUM, K.Y. Adsorption, desorption and mobility of four commonly used pesticides in malaysian agricultural soils. Pesticide Science, v.50, p.53-63, 1997.

GERRITSE, R.G.; BELTRAN, J.; HERNANDEZ, F. Adsorption of atrazine, simazine and glyphosate in soils of the Gnangara Mound, Western Australia. Australian Journal of Soil Research, v.34, p.599-607,1996.

GLASS, R.L. Adsorption of glyphosate by soils and clay minerals. Journal of Agricultural and Food Chemistry, v.35, p.497-500, 1987.

HANCE, R.J. Adsorption of glyphosate by soils. Pesticide Science, v.7, p.363366, 1976.

JACKSON, M.L. Soil chemical analysis: advanced course. Madison: Soil Science Society of America, 1969. 894p. 
JONGE, H.; JONGE, L.W.; JACOBSEN, O.H. $\left[{ }^{14} \mathrm{C}\right]$ Glyphosate transport in undisturbed topsoil columns. Pesticide Management Science, v.56, p.909-915, 2000.

MAQUEDA, C.; MORILLO, E; UNDABEYTIA, T; MARTIN, F Sorption of glyphosate and $\mathrm{Cu}(\mathrm{II})$ on a natural fulvic acid complex: mutual influence. Chemosphere, v.37, p.1063-1072, 1998.

McCONNELL, J.S.; HOSSNER, L.R. pH-Dependent adsorption isotherms of glyphosate. Journal of Agricultural and Food Chemistry, v.33, p.10751078, 1986.

MEHLICH, A. Mehlich 3 soil test extractant: a modification of Mehlich 2 extractant. Comunications in Soil Science and Plant Analysis, v.15, p.1409-1416, 1984.

MENDELSON, J. Round up: o herbicida mais vendido no mundo. The Ecologist, v.28, p.24-27, 1998

MILES, C.J.; MOYE, H.A. Extraction of glyphosate herbicide from soil and clay minerals and determination of residues in soils. Journal of Agricultural and Food Chemistry, v.36, p.486-491, 1988.

NELSON, D.W.; SOMMERS, L.E. Total carbon, organic carbon and organic matter: In: PAGE, A.L. (Ed.) Methods of soil analysis. 2.ed. Madison: ASA, 1982. pt.2, p.539-579.

NOMURA, H.S.; HILTON, H.W. The adsorption and degradation of glyphosate in five Hawaii sugarcane soils. Weed Research, v.17, p.113-121, 1977.

PICCOLO, A.; CELANO, G.; ARIENZO, M.; MIRABELLA, A. Adsorption and dessorption of glyphosate in some Europeans solis. Journal Environmental and Science Health, v.6, p.1105-1115, 1994.
PICCOLO, A.; CELANO, G.; CONTE, P. Adsorption of glyphosate by humic substances. Journal of Agricultural and Food Chemistry, v.44, p.24422446, 1996

PRATA, F.; LAVORENTI, A.; REGITANO, J.B.; TORNISIELO, V.L. Influência da matéria orgânica na sorção e dessorção do glifosato em solos com diferentes atributos mineralógicos. Revista Brasileira de Ciência do Solo v.24, p.947-951, 2000.

RAIJ, B.; QUAGGIO, J.A. Métodos de análise de solos para fins de fertilidade. Campinas: Instituto Agronômico, 1983. 31p. (Boletim Técnico, 81).

ROBERTS, T.R.; HUTSON, D.H.; LEE, P.W.; NICHOLLS, P.H.; PLIMMER, J.R. Metabolic pathways of agrochemicals. Part 1: Herbicides and plant growth regulators. London: The Royal Society of Chemistry, 1998. p.386400.

RODRIGUES, B.N.; ALMEIDA, F.S. Guia de herbicidas. Londrina: Instituto Agronômico do Paraná, 1995. 675p.

RUEPPEL, M.L.; BRIGHTWELL, B.B.; SCHAEFER, J.; MARVEL, J.T. Metabolism and degradation of glyphosate in soil and water. Journal of Agricultural and Food Chemistry, v.25, p.517-528, 1977.

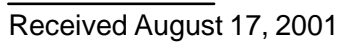

